\title{
Functional Morphology of Adrenergic Innervation of Guinea Pig Spleen
}

\section{SIROŤÁKOVÁ ${ }^{1}$, M. KOČIŠOVÁ ${ }^{2}$, K. SCHMIDTOVÁ ${ }^{2}$, F.DORKO ${ }^{2}$, J. DANKO ${ }^{3}$}

${ }^{1}$ Institute of Experimental Medicine, ${ }^{2}$ Institute of Anatomy, Medical Faculty, P. J. Safárik University,

${ }^{3}$ Department of Anatomy, University of Veterinary Medicine, Košice, Slovak Republic

\author{
Received April 4, 2001 \\ Accepted June 19, 2002
}

\section{Abstract}

Sirotáková M., M. Kočišová, K. Schmidtová, F. Dorko, J. Danko: Functional Morphology of Adrenergic Innervation of Guinea Pig Spleen. Acta Vet. Brno 2001, 71: 159-162.

Innervation of the spleen in guinea-pigs was studied. Adrenergic nerve components of the organ were visualized by glyoxylic acid histofluorescence method. The adrenergic nerve components enter the spleen in a common bundle with arteries. In the organ first they form characteristic dense periarterial plexiform arrangements of thicker and thinner nerve profiles, which are especially conspicuous around the aa. centrales running through the white pulp. Then, nerve fibres extend away from these plexuses into the adjacent layers of fibrous trabeculae, further into the marginal layers of periarterial lymphatic sheath (PALS) as well as into the mantle zone of follicles. Several scattered periarterial and solitary nerve profiles can be seen in the marginal sinuses and cords of the red pulp. Innervation of the wall of large and larger veins is relatively richer than in other mammals. In the fibrous capsule of the spleen several specifically fluorescent nerve fibres can also be seen which have an evident connection with trabecular and parenchymal nerves of the organ.

Microscopic findings support the notion that adrenergic nerve components participate in the regulation of vascular motility as well as in the regulation of the microenvironment of the organ's own parenchyma.

Innervation, lymphoid organ, white pulp, red pulp

Within the context of developing concept on the immuno-neurohumoral regulation of vitally important functions of the organism, special attention has been paid to the study of the anatomical base for neuroregulation of the lymphoid organs. Based upon a more detailed analysis of published data on the nerve supply of spleen in rats and sheep (Felten et al. 1987; Felten and Olshowka 1987; Marettová et. al. 1998) as to the results of our previous works on the study of morphological characteristics of innervation of primary and secondary lymphoid organs in various animals (Schmidtová et al. 1995; Sirotáková and Škardová 1998; Kočišová et al. 1999), we have examined the adrenergic innervation of the spleen in guinea pigs. Participation of the nerve components in the regulation of organ system function appears to be a very interesting problem also in this laboratory animal.

\section{Materials and Methods}

Clinically healthy animals of both sexes were used in the study. The spleens of eighteen 3-4 month-old guineapigs (weighing 300-350 g) were examined. Before experiments, the animals were reared in the Central Animal Husbandy quarters under veterinary care (food and drinking water were supplied ad libitum). The animals were anesthetized with pentobarbital (40 mg $/ \mathrm{kg}$ i.p.). Adrenergic nerve components of the organ were visualized by a modified fluorescent histochemical method of Shvalev and Zhuckova (1987). Both the microscopic examination and photographic documentation were performed using a Jenalumar 2 (Zeiss, Jena).

\section{Results}

Adrenergic nerve components enter the organ in a common bundle with $a$. lienalis and its branches. Then, in the organ they pass together with arteries in the form of typical 
carrying periarterial and also more delicate plexuses, consisting mainly of preterminal and terminal varicose fibres. These fine plexuses lie in close contact with the external side of the muscular media layer, sometimes called "adventitial plexuses". Relatively dense nerve plexuses also accompany the aa. centrales running through the white pulp. In this topography, however, also numerous individual nerve fibres extend away from periarterial or periarteriolar nerve plexuses, which ramify and often do not have a direct connection with perivascular nerves. The nerve formations border arteries and arterioles that pass through the organ, partly within the fibrous trabeculae and partly in the periarteriolar lymphatic sheath (PALS). However, it is necessary to add that next subpopulation of specifically fluorescent nerve fibres also passes through more delicate fibrous trabeculae as far as the fibrous capsule of the organ without apparent connection with vascular branches. Close to the central arterioles only 1-2 accompanying nerve profiles can be seen.

Another characteristic component of the microscopic appearance of adrenergic innervation of the organ consists of numerous individual nerve fibres extending away from the carrying perivascular nerve arrangements, and also from the nerve profiles running through trabeculae and, finally, from the terminal compartment of the adventitial plexuses. In the thicker fibrous trabeculae, these nerve profiles run more or less parallel to the appropriate artery or arteriole, mostly as isolated linear and, sometimes, also branching nerve profiles (Plate V, Figs 1, 2 ) Within PALS they may be seen most often in the marginal zone between the red and white pulp. In addition, specifically fluorescent delicate nerve profiles are also recorded in the mantle zone of lymphatic follicles. However, as a rule, they do not penetrate inside these formations. Individual and branching nerve profiles, however, may be seen also in the marginal sinuses and cords of the red pulp.

The walls of large and larger splenic veins running through trabeculae, unlike in other mammals, are relatively abundantly innervated, while nerve profiles sometimes pass also among the smooth muscular cells of the media. However, they do not form the typical plexiform arrangements of adventitial layer (Plate VI, Fig. 3).

Interestingly, brightly fluorescent periarterial and individual nerve fibres can be also seen in the fibrous capsule of the organ (Fig. 4). Their connection with the nerve components, lying in the adjacent zone of the parenchyma, is mostly quite evident.

\section{Discussion}

Our findings of adrenergic innervation of the guinea-pig spleen are in agreement with the data found in other animals (Bellinger et al. 1987; Felten et al. 1987; Schmidtová et al. 1995) concerning the fact that these nerves enter the organ together with arteries round which they form very conspicuous and typical thicker nerve arrangements that fulfil the role of a carrying substrate, consisting of pre-terminal and terminal varicose fibres. Nerve fibres lie in a close contact with the external side of the musculature of the vascular media to which the vasomotor functions are ascribed. In the zone of diffusibility of the neurotransmitter released from these nerve formations, there are also other structural components of the organ, namely smooth muscular cells of the venous media, lymphatic vessels as well as trabeculae themselves (Felten and Olschowka 1987).

It is well known that all the macro- and microscopic structural characteristics of various components of the organism are formed for certain functions. Like in the spleen is a filter for different non-immune particles of organic or inorganic origin as well as functions of the microenvironment for balanced immune processes. It also has the function of a blood reservoir. Thus, from the morphological view it is evident that reactions of smooth muscular cells to the released neurotransmitter, as in the vascular media of the intrasplenic vascular bed as in fibrous trabeculae of the organ, including fibrous capsule, are the factor that could 
participate, to a great degree, in the regulation of blood flow as well as in its accumulative functions (Bellinger et al. 1987).

So the blood filtration, including physiological decomposition of altered or damaged red blood cells and thrombocytes as well as primary immune responses to antigens carried by blood into the spleen from the internal environment of the organisms, are functions that are realized in the white and red pulp. The presence of specifically fluorescent adrenergic nerve components, however, is recorded not only in trabeculae and close to the vascular media of arterial branches and central arterioles (i.e. in the region of branching terminal and lymphoid tissue-uncapsulated parts of these arterioles), but also in marginal zones round PALS and in the perifollicular topography, including some cords of the red pulp. This all indicate that the processes taking place in these microenvironments are potentially affected by neural modulations (Bellinger et al. 1987). According to Pellas and Weis (1990) in the spleen lymphocytes and sympathetic nerve endings form contacts at a distance that is even shorter than that in a synapse. The presence of surface receptors for the sympathetic neurotransmitters makes lymphocytes susceptible to sympathetic stimulation. Felten et al. (1987) suggested that released neural noradrenalin may influence the functions of the parenchyma entering $\mathrm{T}$ and B-lymphocytes. Furthermore, the processes of the antigen uptake (especially in the labyrinth of very fine vascular walls lined by dendritic cells of the marginal perilymphatic zone round PALS and in the perifollicular topography). Activation of T lymphocytes could be influenced mainly within the range of the PALS borderline layer, whereas the activation of B-lymphocytes take place mainly in the PALS perifollicular and only partially in the marginal zone. The neurotransmitter could, within the range of the external layer of the marginal zone, influence also the entry of lymphocytes into the thinwall initial compartments of the venous bed (Madden et al. 1989; 1994).Our findings of adrenergic nerve fibres in the red pulp are in contrast with data of authors (Felten et al. 1987; Madden et al. 1989) who suggested, that the spleen in the mouse, rat and rabbit is richly innervated by the sympathetic nerve fibres, but these nerve fibres do not enter the red pulp (they extend to the border of the white and red pulp).

There are data (Felten 1993; Felten et al. 1987) indicating that in the spleen, as in other primary and secondary lymphatic organs, fewer nerve profiles are observed with ageing. This has been also confirmed by the studies of the morphometric analysis of adrenergic innervation of the rat spleen (Bellinger et al. 1987), whereas such changes are mostly recorded on the borderline of the white and red pulp because reduction in the white pulp begins with ageing.

Based upon our findings, it may be stated that the patterns of adrenergic innervation of the spleen in guinea pigs agree in principle with those in rats. Only the total number of nerve profiles, supplying larger venous branches and their occurrence in the perifollicular topography, is in guinea-pigs apparently higher.

Our findings are in agreement with those found by the authors who state that adrenergic nerve components supply not only the vasculature, but also the parenchymal component of the spleen, and so they can participate, to a great extent, in the regulation of the immune processes in this organ.

As is known, adrenergic innervation of the spleen represents only one of the means by which the CNS can communicate with the immune system, because the immune functions of the organ may also influence other, i.e. neuroendocrine or peptidergic system.

\section{Funkčná morfológia adrenergickej inervácie sleziny u morčiat}

Autori študovali inerváciu sleziny u morčiat. Adrenergické nervové súčasti znázorňovali pomocou fluorescenčnej histochemickej metódy s kyselinou glyoxylovou.

Adrenergické nervové súčasti vstupujú do orgánu v spoločnom zväzku s artériami. 
V orgáne utvárajú najsamprv charakteristické husté periarteriálne plexiformné zoskupenia hrubších i tenších nervových profilov, ktoré sú obzvlášt nápadné okolo aa. centrales idúce bielou pulpou. Z týchto spletí odbočujú potom priebežne nervové vlákna do prilahlých vrstiev väzivových trabekúl, dalej do marginálnych vrstiev periarteriolárneho lymfatického puzdra (PALS), ako i do pláštovej zóny folikulov. V marginálnych sínusoch a povrazcoch červenej pulpy vidno viaceré periarteriolárne a solitárne nervové profily.

Inervácia steny velkých a väčších vén je bohatšia než u iných cicavcov. Vo fibróznom puzdre sleziny vidno viaceré špecificky fluoreskujúce nervové vlákna, ktoré javia evidentnú spojitost s trabekulárnymi i parenchýmovými nervami orgánu.

Mikroskopické nálezy vyznievajú súhlasne s názormi, že adrenergické nervové súčasti participujú tak na regulácii cievnej motoriky, ako aj na regulácii mikroprostredia vo vlastnom parenchýme tohto orgánu.

\section{References}

BELLINGER, DL, FELTEN, SY, COLLIER, TJ, FELTEN, DL 1987 : Noradrenergic sympathetic innervation of the spleen: IV. Morphometric analysis in adult and aged F344 rats. J Neurosci Res 18: 55-63

FELTEN, DL 1993: Direct innervation of lymphoid organs: Substrate for neurotransmitter signaling cells of the immune system. Neuropsychobiology 28: 110-112

FELTEN, DL, ACKERMAN, KD, WIEGAND, SJ, FELTEN, SY 1987: Noradrenergic sympathetic innervation of the spleen: Nerve fibres assotiate with lymphocytes and macrophages in specific compartments of the splenic white pulp. J Neurosci Res 18: 28-36

FELTEN, SY, OLSCHOWKA, J 1987: Noradrenergic sympathetic innervation of the spleen: II. Tyrosine hydroxylase (TH)-positive nerve terminals form synaptic-like contacts in the splenic white pulp. J. Neurosci Res 18: $37-48$

KOČIŠOVÁ, M, SIROŤÁKOVÁ, M, DORKO, F, SCHMIDTOVÁ, K, RYBÁROVÁ, S, MIKLOŠOVÁ, M, KLUCHOVÁ, D 1999: The innervation of the bursa cloacalis. Biologia 54/Suppl. 6: 115-119

MADDEN, KS, FELTEN, SY, FELTEN, DL, SUNDARESAN, PR, LIVNAT, S 1989: Sympathetic neural modulation of the immune system. Brain Behav Immunol 3: 72-81

MADDEN, KS, MOYNIHAN, JA, BRENNER, GJ, FELTEN, SY, FELTEN, DL, LIVNAT, S. 1994: Sympathetic nervous system modulation of the immune system. III. Alterations in T and B cell proliferation and differentiation in vitro following chemical sympathectomy. J Immunol 49: 77-87

MARETTOVÁ, E, NAĎOVÁ, P, MARETTA, M 1998: Immunohistochemical localization of S-100 protein in the sheep spleen. Folia Veterinaria 42: 19-22

PELLAS, TC, WEIS, L 1990: Deep splenic lymphatic vessels in the mouse: A route of splenic exit for recirculating lymphocytes. Am J Anat 187: 347-354

SCHMIDTOVÁ, K, BÁNOVSKÁ, E, MIKLOŠOVÁ, M 1995: Development and distribution of acetylcholinesterase (AChE)-positive nerve fibres in the spleen of the rats and chickens. Folia Veterinaria 39: 75-77

SIROŤÁKOVÁ, M, ŠKARDOVÁ, I 1999: The innervation of the thymus of the rat. Folia Veterinaria 43: 144-146

SHVALEV, VN, ZHUCKOVA, N 1987: An improvement in histochemical findings in adrenergic nerve elements in glyoxylic acid solution with the aid of dimethylsulphoxide (DMSO). Ark Anat 93: 91-92 
Plate V

Sirotáková M. et al.: Functional... pp. 159-162

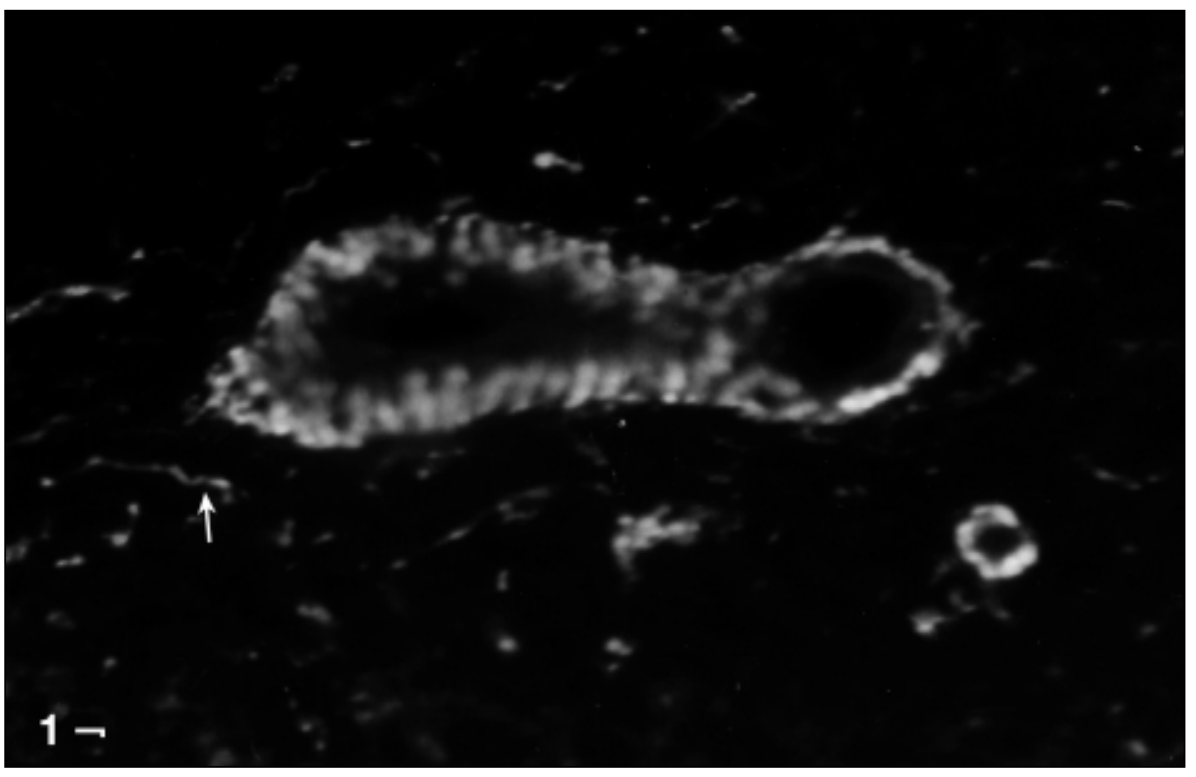

Fig. 1. In a trabecula around the abundant adrenergically innervated small arterial branch can be seen solitary and partially ramified nerve profiles whose origin from adrenergic periarterial nerve plexuses is evident only sporadically (arrow). Bar $=30 \mu \mathrm{m}$

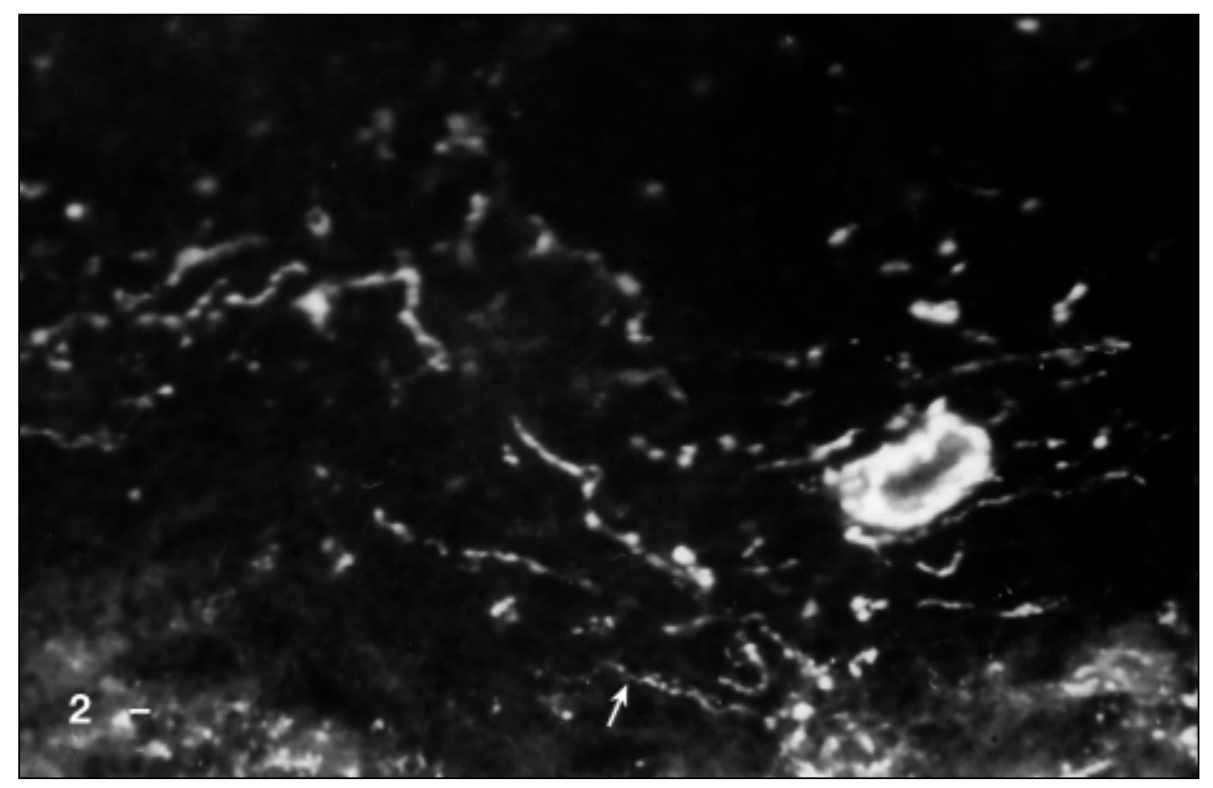

Fig. 2. Plexiform arrangement of solitary nerve profiles around the terminal parts of the septum-running arteriole and its diversion a. centralis (arrow). Bar $=30 \mu \mathrm{m}$ 
Plate VI

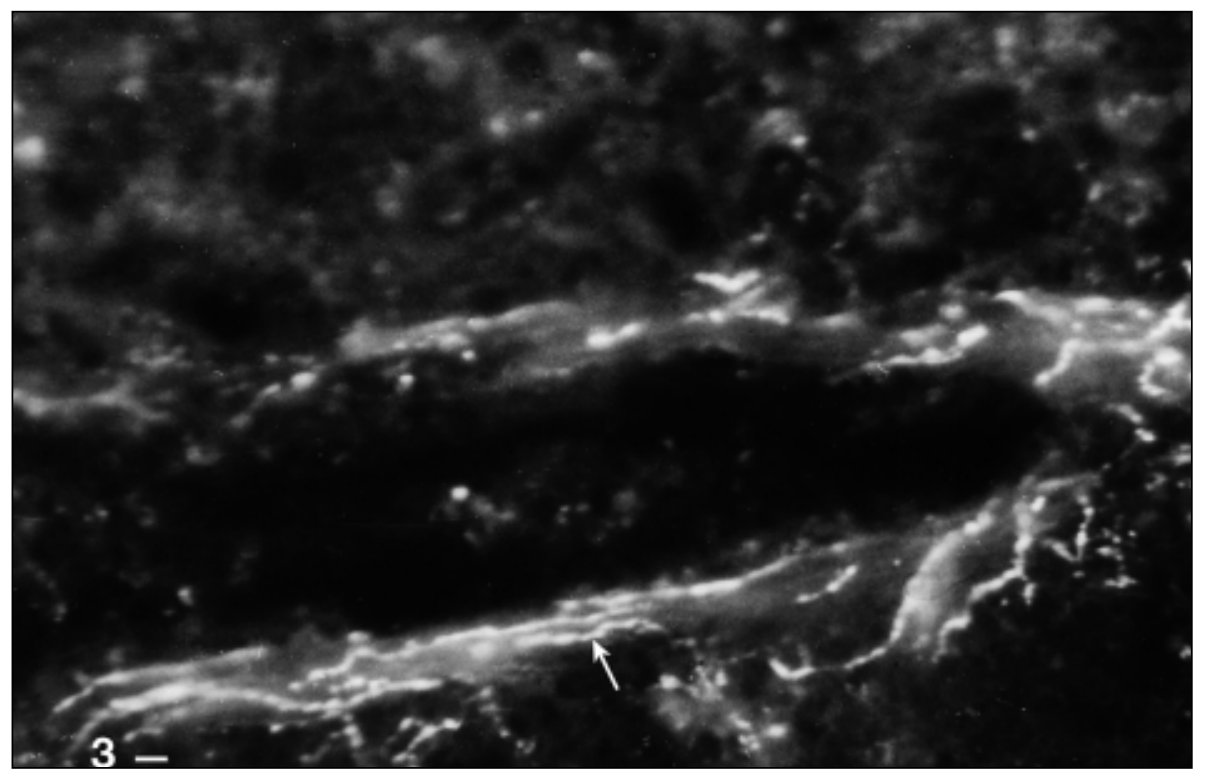

Fig. 3. A conspicuosly dense and intesively fluorescent nerve plexuses around the wall of the large vein running through the trabecula in close vicinity to the organ hilus. Nerve fibres also supply to muscular layer of the vascular wall and also lie, occasionally, under the endothelium (arrow). Bar $=30 \mu \mathrm{m}$

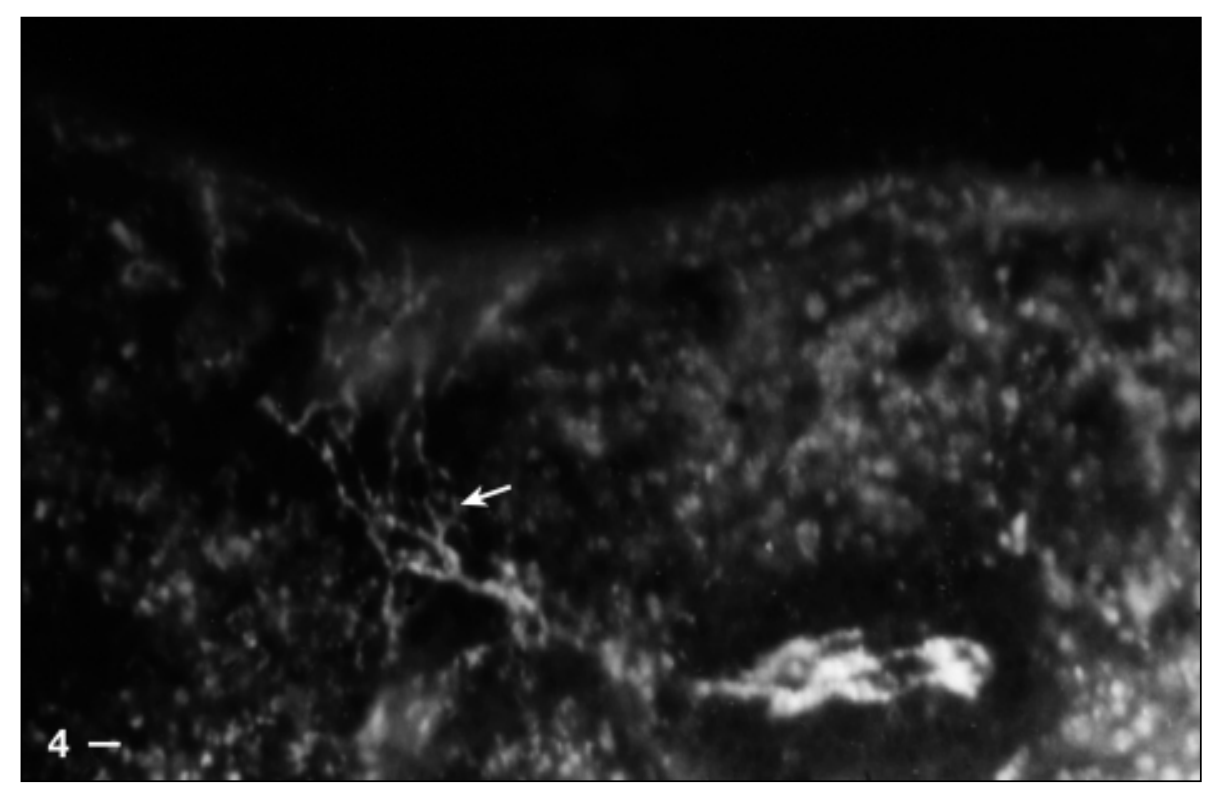

Fig. 4. The connection of intrasplenic nerve components with nerve profiles in the fibrous capsule of the organ (arrow). Bar $=30 \mu \mathrm{m}$ 